adequate attention. Fully treated are problems of personnel management, including selection, records, classification, and the training of new staff members. Proper retirement plans are discussed.

Questions of staff organization and meetings and other coordinating devices are reviewed, and formal recommendations of policy are suggested.

Mr. Wight's book dealing with library finance and accounting is a useful contribution to the subject. Sources of revenue are discussed, including state and federal aid, and methods are suggested for the proper building and operation of the budget. The book concludes with two chapters on library accounting. The latter of these is a distinct contribution to the sparse literature on library cost accounting, a subject likely to receive more attention in the future.

These two volumes are valuable additions to the growing list of reference manuals on specific library problems. They will serve the administrator as conveniences. They should be especially useful to teachers in library schools. Both volumes contain selected bibliographies. Mr. Wight's work has, as a supplement, a glossary of accounting terminology.-Robert J. Usher, ${ }^{1}$ HowardTilton Memorial Library, Tulane University, New Orleans.

1 Mr. Usher died on August 3, after his review of the McDiarmid and Wight books had been set in type for inclusion in this issue of College and Re. search Libraries.

\title{
Classics of The Western World
}

Classics of the Western World. Alan Willard Brown and members of the faculty of Columbia College, editors. With a foreword by John Erskine. Third edition, completely revised and rewritten. I45p. Chicago, American Library Association, I943.

The extensive interest of recent years in "the great books" may account for the preparation of a new edition of the Columbia University list which for some twentyfive years had served the purposes of the undergraduate honors course of that university. It is gratifying to the compilers to observe that it was this list, in turn, which occasioned so much public interest in "the one hundred great books" and in other enumerations and selections. The greatest advertisement of these laureati came from St. John's College of Annapolis, where they were made (with many additions and omissions) the substance of the course of study. St. John's makes revisions at will, which means, so far, quite frequently. Considering the purposes of the Columbia Colloquium, as the honors course is now styled, and the further purpose of the compilers to serve the intellectual public, we can readily understand that alterations of previous curricula would become desirable.
It was the leading purpose of earlier editions of this bibliography to enlarge "the pleasure of reading." The present edition does not employ this phrase but in its place are the expressions, "the formation of a good man and a wise citizen," "voluntary self-education," "the preservation and understanding of our democratic heritage," "the layman of eager mind who desires to know the nature, tone, and quality of our intellectual tradition," and others which indicate that liberal education by way of private reading is now the uppermost concern. However, we find here "very few of the major contributions to pure science" as well as "many omissions among historians and writers on political economy," not to speak of the "serious limitations" upon the competency of the scholars -of whom there are eight-who, we are surprised to read, dictated the exclusion of all works of the Orient and of Latin America. Only the excessive modesty of this, let us suppose, is a match for the supposition that these learned men are unacquainted with Lao-Tse, the Bhagavad-Gita, the Upanishads, or with the Latin American writers whom they would rank with the immortals. In the event they did not have the cooperation of the departments at Columbia which study the Orient and Latin America, why did they not apply 
themselves, guided by the same prescription which this volume offers to "the layman of eager mind," and find out what they needed to know about the literature of these other lands? They had the warrant of John Erskine, in his graceful preface still happily carried from the previous editions, that even without an introductory study any reader can discover and enjoy the substance of great books, provided they are not of a highly specialized scientific character.

This edition like those before gives first the title or titles which are considered most available from each of the chosen authors, then gives the secondary titles, and lastly a critical bibliography, brought up to date, of the literature on each author is provided. Sixty-five authors are added, while nine of those previously chosen have been dropped, and the total number of authorships now is about I50. The following were dropped: Petrarch, Leonardo, Grotius, Newton, Bentham, Malthus, Pasteur, Galton, Tolstoy. They might be said to have made room for these: Samuel Richardson, Byron (ten titles!), Leopardi, Hugo, Berlioz the composer, Gogol, Whitman, Henry George, and Bernard Shaw. Some other additions are: Demosthenes, Plautus, Terence, Caesar, $\mathrm{Ca}$ tullus, Livy, Seneca, Petronius, Tacitus, Boethius, Abelard and Heloise, Saint Bonaventure, Luther, Calvin, Hooker, Ben Jonson, Sir Thomas Browne, Smollett, Lessing, Burke, Boswell, Blake, Wordsworth, Coleridge, Pushkin, Newman, Emerson, Hawthorne, Melville, Mark Twain, Henry James, Arnold, Meredith, Samuel Butler, Turgenev, Chekhov, Bergson, Proust, Joyce.

Professor Erskine's preface remarks that while the reader "will think of many titles which to him seem to deserve a place here or which seem more important than some of the titles here given ... there is no reason why all points of view and all shades of taste should be included." However, the reader will also think that a restrictive point of view should be acknowledged and justified, where the purpose is so broad as it is in this library. These are the classics of the Western World, we are to understand, rather than of eight of the staff of Columbia. Unless good reasons are given-and we might say exceptional if not original reasons-we are not likely to understand the inclusion of Pamela among the classics when Tristram Shandy, with the rest of its author's work, is left out; or that of Turgenev (and Gogol) when Manzoni is not admitted; or the preference of Byron and Whitman to Keats and Browning (as well as to Shelley and Hopkins, to name two others). The most lucid intellect of today in fields the most difficult and one possessed of great originality and much artistry-Bertrand Russell-finds no place here except in the mention of one or two of his minor writings, while the celebrated doctor of the "libido," S. Freud, is allowed more than a page. F. H. Bradley is not mentioned, though it would be difficult to name ten men equal to him, in brilliance, depth, or ingenuity of style, in all of English literature. C. M. Doughty, whose style was as enchanting as his subject matter, is not mentioned. Others will come to mind, as Professor Erskine anticipates. On the other hand, the addition of many names which must have been missed before, will gratify serious users of the list. Some examples: Leibniz, Marlowe, Schiller, Stendhal, Flaubert (how were these ever omitted?); also Lope de Vega, Donne, Meredith (eleven titles), and Thoreau (but not his fascinating Week on the Concord and Merrimack Rivers).

\section{Changes Within Authors' Works}

We notice a great many changes of judgment concerning the merits of a given author's works during the interval between the last edition of this compilation and the edition now published. The selections from Plato, for example, gave first place to the Symposium before, whereas that rank now goes, surprisingly, to the $A$ pology, and three additional works are given precedence over the Symposium. Of Sophocles the Oedipus Tyrannus was formerly the highest in esteem but now it is omitted and the Antigone stands first. The book of Amos, in the Old Testament, has advanced from ninth rank to second, while some other books that were formerly recommended and also some of the Psalms, are not cited in the present edition. 
Shakespeare's Hamlet, which was eighth in favor among his works before, is now first. Formerly Pere Goriot was thought the first of Balzac's works, while now it has fallen from favor entirely, not appearing in the new selections at all. Many other reversals of judgment will be noticed. No explanation of this is found. The student, and especially one who was without the benefit of instruction, might be seriously perplexed if he were using an earlier edition and happened to discover the changes in the new one. He would not be reassured, we may surmise, were he to hear from eminent critical authority, or to discover for himself, that Henry Esmond is much above $V$ anity $F$ air in the novelist's art, yet found the reverse consistently pronounced in the several editions of this catalog.

Persons who have the most use for a handy guide to literature will find little to dissuade them in discrepancies like these. Although the editors reject the aim of quick and easy education, it is probably the individual in search of just that who most often turns to aids of this kind. Nowadays this individual frequently holds a college degree. If it is a liberal arts degree, he ought to know enough about great authors to make his own selections, but President Hutchins has stated that a youth can now pass through college and acquire a degree without having read a single great book understandingly. This is not because he lacks time-what else is his time for? $\mathrm{He}$ has time to acquaint himself well with one important book for each semester hour of serious college study, or, conservatively, about one hundred books during a four-year course. That "new programs" should have to be introduced to accomplish this; that it should be regarded as something remark- able, even revolutionary; that it should become a matter of controversy, with the largest party resolutely opposing it-such is a sign of something seriously wrong with college education. The shortcoming of the college is indicated by the desire of some, after the romance of the campus, for reading courses and for trustworthy selections which will answer to the aspirations of an active spirit. Many lists have been prepared, from the ten books which newspaper gossipers are fond of selecting in the event of their banishment to a deserted island, to the nine hundred or more titles of Everyman's Library.

\section{Advantage of List}

The advantage of the revised Columbia list, no doubt, is its suitability to persons who have an eager mind and a literary sense, without necessarily having technological or scientific training, plus the inclusion of many books and essays expounding and critically appraising the chosen works. It is possible for a reader to question, on good grounds, the omission of this or that critique in favor of some other, and the same might be said of some of the translations of the texts. If he is a student of Aeschylus or Leibniz, for example, he may disagree in the one case concerning the translations and in the other concerning the commentaries, while if he should be a disciple of C. S. Peirce, he might justly complain that there is no longer any reason for tolerating the printer's misspelling of the name of one of our acutest authors. These minutiae apart, he will find this an instructive handbook, opening treasures for a lifetime.-Peter A. Carmichael, Professor of Philosophy, Louisiana State University, Baton Rouge. 